\title{
In vivo and in vitro pharmacological activities of Tacca integrifolia rhizome and investigation of possible lead compounds against breast cancer through in silico approaches
}

Shahriar Ahmed', Ahmed Rakib', Md. Ashiqul Islam¹, Bibi Humayra Khanam¹, Farhana Binta Faiz', Arkajyoti Paul ${ }^{2,3}$, Md. Nazim Uddin Chy ${ }^{2,4}$, N. M. Mahmudul Alam Bhuiya ${ }^{5}$, Mir Muhammad Nasir Uddin', S. M. Amanat Ullah ${ }^{6}$, Md. Atiar Rahman ${ }^{7}$ and Talha Bin Emran ${ }^{2,78^{*}}$ (i)

\begin{abstract}
Background: The study was conducted to evaluate the analgesic, anti-inflammatory, antipyretic properties of ethanolic extract of Tacca integrifolia rhizome (EETI) in mice and cytotoxic effects in brine shrimp nauplii followed by a PASS prediction study for some isolated compounds of T. integrifolia. Additionally, this experiment included the in silico molecular docking and ADME/T property analyses of some phytochemicals.
\end{abstract}

Methods: Formalin- induced paw licking test and acetic acid-induced writhing test for analgesic activity, carrageenaninduced paw edema test for anti-inflammatory potential and Brewer's yeast-induced pyrexia test for antipyretic activity were applied. Antinociceptive and antineoplastic activity for breast cancer were revealed with PASS program.

Schrodinger suite 2015 was used to evaluate the binding interaction and ADME/T properties of selected phytoconstituents with estrogen receptor alpha.

Results: In formalin-induced paw licking test, EETI at the doses of 200 and $400 \mathrm{mg} / \mathrm{kg} \mathrm{BW}$ showed highly significant inhibition of writhing in both neurogenic and inflammatory phases. While EETI also exhibited highly significant, compared to control, writhing inhibition for both the doses in acetic acid-induced writhing test. Moderate antiinflammatory effect at a dose of $400 \mathrm{mg} / \mathrm{kg}$ BW was noticed in paw-edema test. It also showed $77.51 \%$ of maximum antipyretic effect which was significantly effective compared to standard drug paracetamol $(150 \mathrm{mg} / \mathrm{kg})$ in Brewer's yeast-induced pyrexia test. The EETI showed potential cytotoxic activity with $\mathrm{LC}_{50}$ value of $114.46 \mu \mathrm{g} / \mathrm{mL}$. The PASS prediction revealed the potential antinociceptive and antineoplastic activity of target compounds. The compounds betulinic acid, quercetin-3-a-arabinoside, catsanogenin were found to be effective in molecular docking study.

Conclusion: It is evident that the EETI possesses highly significant analgesic activity with remarkable anti-inflammatory and antipyretic activity. The phytoconstituents have potential antinociceptive and antineoplastic (breast cancer) activity.

Keywords: Tacca integrifolia, Analgesic, Anti-inflammatory, Antipyretic, PASS prediction, Breast cancer, Molecular docking

\footnotetext{
* Correspondence: talha-bgctub@bgctrustbd.org; talhabmb@gmail.com

²Drug Discovery, GUSTO A Research Group, Chittagong 4000," Bangladesh

${ }^{7}$ Department of Biochemistry and Molecular Biology, University of

Chittagong, Chittagong 4331, Bangladesh

Full list of author information is available at the end of the article
} 


\section{Introduction}

Pain, inflammation, and fever are the most common features people suffer from. The search for medication against nociception, inflammation, and pyrexia is increasing day by day due to the unwanted effects of existing anti-inflammatory, analgesics and antipyretic drugs [1]. Therefore, an alternative, safer and effective option is urgent to be searched. Plants and herbs have been used in Asian countries in traditional medicine to obtain analgesic, anti-inflammatory, and antipyretic effects [2, $3]$. The brine shrimp lethality bioassay is an effective, quick and accessible that requires only a tiny amount of sample. This bio-analysis has a good contextual connection with cytotoxic activity in solid tumors and also possessed pesticidal activity. The bioassay also paves the way for the innovation of annonaceous acetogenins as an active antitumor agent [4].

Virtual screening has an especial meaning to understand the pharmacological effect of the phytoconstituents [5]. Depending on the structural formula of the substances, the prediction of activity spectra for substances (PASS) software predicted greater than 4000 bioactivities [6]. Breast cancer is the most general cancer among the women in Western countries. One of the main reason of breast cancer is estrogen receptor alpha $(E R-\alpha)$. Breast cancer is due to the overexpression of ER$\alpha$ in a number of cases. Breast cancer begins in the inner lining of milk ducts and spread to the other parts of the body. In silico molecular biology uses computational models via computer simulation as used in systemic biology. As a result of a plenty of amount of data is now produced by molecular and experimental biologists, computational biology is surprisingly mandatory to handle it. Molecular docking analysis is also an in silico techniques, which methods are fundamental for the designing and planning of newer drug molecules using computer-aided drug discovery (CADD) techniques. A successful molecular docking must be able to dictate the native ligand pose with the binding site of the threedimensional protein structure and associated with physicochemical interactions [7].

In this study, we evaluated the pharmacological attributes of Tacca integrifolia Ker Gawl. (Family: Taccaceae). The plant is a herb found in the forests of Chittagong, Chittagong Hill Tracts, and Moulavi Bazar, which is locally known as "Bara Hikand" and tubers are used as digestive and tonic [8]. In traditional medicine of Myanmar, its rhizomes have been used for the treatment of carbuncles, skin abrasion, skin diseases, and various kinds of cancers [9-12]. In our current study, the crude rhizome extract of $T$. integrifolia were studied to explore their analgesic, anti-inflammatory, antipyretic, cytotoxic activities and also an in silico analysis of the antineoplastic (breast cancer) and antinociceptive activity using
PASS program and molecular docking analysis with estrogen receptor alpha with the constituents obtained from the rhizome of $T$. integrifolia as well as the ADME/ $\mathrm{T}$ analysis.

\section{Materials and methods}

\section{Plant material}

The rhizome of the plant of $T$. integrifolia was collected from Sreemangal Upazila, Moulvibazar, Sylhet, Bangladesh during the month of October and November and identified by Dr. Sheikh Bokhtear Uddin, Chittagong University Herbarium, Department of Botany, University of Chittagong, Chittagong-4331, Bangladesh. A voucher specimen (accession no. 1108) has been preserved in the institutional herbarium of the aforesaid Department.

\section{Extraction of the plant material and sample preparation}

At first, the rhizomes were washed with tap water carefully before cut into small pieces and then dried for 7 days in shade at $22-28^{\circ} \mathrm{C}$. Afterward, the pieces were grinded by a mechanical grinder and then passed through a size 60 mesh to obtain the fine powder. The materials were stored in an air-tight container. The resulting powder $(600 \mathrm{~g})$ was put in a clean roundbottom Erlenmeyer flask $(5 \mathrm{~L})$ and soaked in $4 \mathrm{~L}$ of ethanol for 15 days at room temperature with occasional shaking and stirring. The filtrate was collected through cotton plug followed by a Whatman no. 1 filter paper and evaporated by a Heidorph rotary evaporator at $45^{\circ} \mathrm{C}$. That left us a gummy concentrate of dark yellow brownish color crude extract (w/W, 4.08\%). At last, the crude extract was dried by freeze drier and preserved at $4{ }^{\circ} \mathrm{C}[13]$.

\section{Chemicals and reagents}

The chemicals used were: ethanol, acetic acid (Merck, Germany), Diclofenac sodium, Paracetamol (Eskayef Bangladesh Limited, Tongi, Bangladesh), normal saline solution (Orion Infusion Limited, Bangladesh) and Tween-80 (Sigma-Aldrich). Rests of the chemicals were of BDH and E-Merck analytical grade. Brewer's yeast was collected from the local market.

\section{Experimental animals}

For the experiment, adult Swiss albino mice (BALB/c) weighing between $(12-30 \mathrm{~g})$ of either sex were collected from animal house of International Centre for Diarrheal Disease and Research, Bangladesh (ICDDR, B), Dhaka. The animals were maintained under normal laboratory condition and kept in standard polypropylene cages at room temperature of $(25 \pm 2){ }^{\circ} \mathrm{C}$ and $60 \%$ to $65 \%$ relative humidity and provided with standard diet and water. Each group consists of five mice and to denote individual animal, they were marked as the group I, II, III, IV 
for test samples at the doses of 200 and $400 \mathrm{mg} / \mathrm{kg} \mathrm{BW}$ and a normal control and positive control group was also maintained for whole intervention. Animals were handled and maintained according to the guidelines of Institutional Animal Ethics Committee of the Faculty of Biological Science of the University of Chittagong, Bangladesh (AERB/FBS/UC/02, 2015).

\section{Acute toxicity test}

Mice were divided into nine groups, each group consisting of five animals. Group I was given 1\% Tween-80 in normal saline $(2 \mathrm{~mL} / \mathrm{kg} \mathrm{BW})$. The other eight groups (Groups II-IX) were administered, respectively, 100, 200, 400, 600, 800, 1000, $2000 \mathrm{mg}$ of per $\mathrm{kg} \mathrm{BW}$. All animals were closely observed for the next $8 \mathrm{~h}$ to notice any behavioral changes or mortality and were kept under close observation for the next two weeks [14].

\section{Phytochemical screening}

EETI was qualitatively evaluated for the detection of alkaloids, glycosides, phenolics, terpenoids, carbohydrates, flavonoids, steroids, tannins, saponins following standard procedures [15].

\section{Analgesic activity}

\section{Formalin-induced paw licking test}

Animals were given $20 \mu \mathrm{L}$ of $2.5 \%$ formalin solution (7\% formaldehyde) made up in saline and injected intraperitoneally in the ventral surface of the right-hand paw. Animals were observed from 0 to $5 \mathrm{~min}$ (neurogenic phase) and 15-30 min inflammatory phase and the time spent licking the injected paw was recorded as indicative of nociception. The animals were given EETI at 200 and $400 \mathrm{mg} / \mathrm{kg}$ BW $1 \mathrm{~h}$ before, with the basis of a previous time response curve. Positive control group received standard drug Diclofenac sodium at the dose of $10 \mathrm{mg} /$ kg BW $[16,17]$.

\section{Acetic acid-induced writhing test}

The analgesic activity of the extract was studied using the acetic acid-induced writhing model in mice [18]. The animals were divided into normal control, positive control and test groups with five mice in each group. The animals of test groups received test samples at the doses of 200 and $400 \mathrm{mg} / \mathrm{kg} \mathrm{BW}$. The positive control group received standard drug Diclofenac sodium at the dose of $10 \mathrm{mg} / \mathrm{kg} \mathrm{BW}$. Test samples were administered orally $30 \mathrm{~min}$ before intraperitoneal administration of $0.6 \%$ acetic acid and also Diclofenac sodium was administered $30 \mathrm{~min}$ before injection of acetic acid. After an interval of $5 \mathrm{~min}$, the mice have observed for specific contraction of the body referred to as 'writhing' for the next $30 \mathrm{~min}$.

\section{Anti-inflammatory activity}

\section{Carrageen induced paw edema test}

The anti-inflammatory activity was measured on mice of either sex (25-30 g). The animals were randomly divided into five groups each of six animals [19]. Group I was administered with normal saline $(10 \mathrm{~mL} / \mathrm{kg})$, group II with Diclofenac sodium $(10 \mathrm{mg} / \mathrm{kg})$, rest of the groups were treated with EETI (200 and $400 \mathrm{mg} / \mathrm{kg}$, i.p.). After 30 mins of the above intraperitoneal administration, carrageenan $(1 \%, 0.05 \mathrm{~mL})$ was injected subcutaneously in the subplantar tissue of the right hind paw of each mouse. The inflammation was measured using plethysmometer (LE 7500 plan lab S.L) immediately after injection of carrageenan and then 1,2, 3 and $4 \mathrm{~h}$. The average foot swelling in a drug-treated animal, as well as standard, was compared with that of control and the percent inhibition (anti-inflammatory activity) of edema was determined using the formula.

$$
\text { Percent inhibitation }=(A-B) / A \times 100
$$

Where A represents edema volume of control and B as paw edema of tested group.

\section{Antipyretic activity Brewer's yeast-induced pyrexia}

The antipyretic activity of EETI was done by using BALB/c mice (25-30 g) of either sex. The animals were divided into five groups each of five mice. The normal body temperature of each mouse was recorded using a digital thermometer and then pyrexia was induced in all mice by injecting $20 \%$ aqueous suspension of Brewer's yeast $(10 \mathrm{~mL} / \mathrm{kg}$, s.c.). All groups were fasted overnight but allowed free accesses to drink water and after the 24 $h$ rectal temperature of each mouse was recorded. The induction of pyrexia was confirmed by rising in temperature more than $0.5^{\circ} \mathrm{C}$, while animals showed a rise in temperature less than $0.5^{\circ} \mathrm{C}$ were excluded from experiment [20]. Group I received saline $(10 \mathrm{~mL} / \mathrm{kg})$ as a negative control, Group II received Paracetamol (150 $\mathrm{mg} / \mathrm{kg}$ ) as a standard drug while the remaining groups III and IV received 200 and $400 \mathrm{mg} / \mathrm{kg}$, i.p. EETI respectively. After drugs administration, rectal temperature was again recorded periodically at $1,2,3$ and $4 \mathrm{~h}$ of drugs administration. The percent reduction in pyrexia was calculated by the following formula.

$$
\text { Percent reduction }=\frac{B-C n}{B-A} \times 100
$$

Where, $\mathrm{B}$ represents temperature after pyrexia induction; $\mathrm{Cn}$, temperature after $1,2,3$ and $4 \mathrm{~h}$ and $\mathrm{A}$, normal body temperature. 


\section{Cytotoxicity assay}

\section{Brine shrimp lethality bioassay}

The brine shrimp lethality bioassay was carried out by the method described by Meyer et al., [21] for investigating the cytotoxicity of EETI. First of all, the dried extract preparations were dissolved in DMSO to obtain a solution of $10 \mathrm{mg} / \mathrm{mL}(1000 \mu \mathrm{g} / \mathrm{mL})$ and from the stock solution, concentration of $800 \mu \mathrm{g} / \mathrm{mL}, 600 \mu \mathrm{g} / \mathrm{ml}, 400 \mu \mathrm{g} / \mathrm{mL}$, $200 \mu \mathrm{g} / \mathrm{mL}, 100 \mu \mathrm{g} / \mathrm{mL}$ were made. The standard drug, Vincristine sulphate (VS) was used as positive control at concentrations $5 \mu \mathrm{g} / \mathrm{mL}-0.156 \mu \mathrm{g} / \mathrm{mL}$. $5.0 \mathrm{~mL}$ of artificial seawater (made by using sea salt $38 \mathrm{~g} / \mathrm{L}$ and the $\mathrm{pH}$ was adjusted to 8.5 using $1 \mathrm{~N} \mathrm{NaOH}$ ) was added into all the test tubes. Brine shrimp (Artemisa salina) was used as a suitable monitor for the cytotoxicity screening. The eggs of the brine shrimps were collected from local aquarium shop (Chittagong, Bangladesh) and hatched in artificial seawater under constant air supply for $24 \mathrm{~h}$ under appropriate light. The hatched shrimps were allowed to grow by $48 \mathrm{~h}$ to get nauplii (Brine shrimp larvae). After $48 \mathrm{~h}$, the active nauplii were attracted to one side in a glass Petri dish by using a micropipette. The nauplii were then separated from the eggs by aliquoting them in another glass petri dish containing artificial sea water and used for the assay. The suspension containing 10 nauplii was added into each test tube and was incubated at room temperature $\left(25 \pm 1^{\circ} \mathrm{C}\right)$ under light for 12 $\mathrm{h}$. The tubes were then assessed after $24 \mathrm{~h}$ and the number of surviving nauplii in each tube was counted by a $3 \mathrm{X}$ magnifying glass. Experiments were conducted along with VS in a set of three tubes per dose. The concentration that would kill $50 \%$ of the nauplii $\left(\mathrm{LC}_{50}\right)$ was determined from a linear regression equation using the software "Microsoft Excel 2013".

\section{Selection of compounds for PASS prediction}

The compounds betulinic acid, catsanogenin, quercetin-3$\alpha$-arabinoside, chantrieroside A, taccasuboside $D, n$ triacontanol, taccabulin A, taccalonolide AA, taccalonolide $\mathrm{AB}$, taccalonolide $\mathrm{Z}$ were selected based on the availability in T. integrifolia as major compounds through literature survey [10, 22]. Amongst them, betulinic acid, catsanogenin, quercetin-3- $\alpha$-arabinoside, chantrieroside $A$, taccasuboside $\mathrm{D}, \mathrm{n}$-triacontanol, taccabulin $\mathrm{A}$, taccalonolide $\mathrm{Z}$ were collected from PubChem database and taccalonolide AA, taccalonolide AB were drawn using ChemDraw v 17.

\section{In silico experiment to predict the activity spectra for substances (PASS)}

The selected phytoconstituents i.e. betulinic acid, catsanogenin, quercetin-3- $\alpha$-arabinoside, chantrieroside $A$, taccasuboside $\mathrm{D}$, $\mathrm{n}$-triacontanol, taccabulin $\mathrm{A}$, taccalonolide $\mathrm{AA}$, taccalonolide $\mathrm{AB}$, taccalonolide $\mathrm{Z}[10,22]$ were subjected for evaluating the antinociceptive and antineoplastic (breast cancer) activity with the help of the PASS program. This analysis predicts the spectrum of activity of a compound as probable activity $\left(\mathrm{P}_{\mathrm{a}}\right)$ and probable inactivity $\left(\mathrm{P}_{\mathrm{i}}\right)$ [23] based on the structureactivity relationship (SAR) analysis of the training set consisting of more than 2,05,000 compounds showing more than 3750 types of bioactivities. The $\mathrm{P}_{\mathrm{a}}$ and $\mathrm{P}_{\mathrm{i}}$ values lie between 0.000 to 1.000 . If the value of $\mathrm{P}_{\mathrm{a}}>\mathrm{P}_{\mathrm{i}}$, then it assumed that the compound is experimentally active. When the $\mathrm{P}_{\mathrm{a}}$ value is greater than 0.7 , it means high pharmacological potentiality and the values following $0.5<\mathrm{P}_{\mathrm{a}}<0.7$ demonstrates the considerable pharmacological activity experimentally. When the value of $\mathrm{P}_{\mathrm{a}}<$ 0.5 , the value exhibits a less pharmacological activity which may convey an opportunity for finding the new compound $[24,25]$.

\section{In silico molecular docking analysis Protein preparation}

Three-dimensional crystal structures of estrogen receptor alpha (PDB ID: 3ERT) was downloaded in PDB format from the protein data bank [26]. After downloading as PDB format, the structure was prepared and refined using the Protein Preparation Wizard of Schrödinger-Maestro v10.1. Charges and bond orders were assigned, hydrogens were added to the heavy atoms, selenomethionines were converted to methionines, and all waters were deleted. Using force field OPLS_2005, minimization was carried out setting maximum heavy atom RMSD (root-meansquare-deviation) to $0.30 \AA$.

\section{Ligand preparation}

The target compound i.e. betulinic acid (PubChem CID: 64971), catsanogenin (PubChem CID: 436072), quercetin3- $\alpha$-arabinoside (PubChem CID: 5481224) were obtained from PubChem database. The 3D structures of the ligands were built by using Ligprep in Schrodinger Suite 2015 with the OPLS_2005 force field. The pH 7.0 \pm 2.0 was used for the generation of ionization states of the compounds which used Epik 2.2 in the Schrödinger suite. Up to 32 possible stereoisomers per ligand were retained.

\section{Receptor grid generation}

Receptor grids were calculated for the prepared proteins for the observation of poses by various ligands bind within the active predicted site during the docking procedure. In Glide, grids were generated keeping the default parameters of van der Waals scaling factor 1.00 and charge cutoff 0.25 subjected to the OPLS_2005 force field. A cubic box of specific dimensions centered on the centroid of the active site residues was obtained for the receptor. The bounding box was set to $14 \times 14 \times 14$ for docking experiments. 
Glide standard precision (SP) ligand docking

SP flexible ligand docking was carried out in Glide of Schrödinger-Maestro v10.1 $[27,28]$ within which penalties were applied to non-cis/trans amide bonds. For ligand atoms, Van der partial charge cutoff and scaling factor were selected to be 0.15 and 0.80 , respectively. Final scoring was done on energy-minimized poses and showed as Glide score. The best-docked pose with the lowest Glide score was recorded for each ligand.

\section{ADME/T property analysis}

\section{Ligand base ADME/toxicity prediction}

The QikProp module of the Schrödinger (Maestro v10.1) is a quick, precise, easy-to-use absorption, distribution, metabolism, and excretion (ADME) prediction program designed to get certain descriptors linked to ADME. It predicts both pharmacokinetic and physicochemical significant descriptors relevant properties. ADME properties ascertain drug-like activity of ligand molecules based on Lipinski's rule of five. ADME/T properties of the compound (betulinic acic, quercetin-3$\alpha$-arabinoside, and catsanogenin) were analyzed by QikProp 3.2 module [29].

\section{Statistical analysis}

The results obtained were expressed as mean \pm SEM (Standard error of mean) of five animals. For statistical analysis, ANOVA was followed by post hoc Dunnett's test for multiple comparisons. Effects were considered to be significant at the $p<0.05$ level. The statistical analysis was carried out in SPSS (version 16.0).

\section{Results}

\section{Acute toxicity test}

The current study confirmed that oral administration of the EETI is safe as none of the doses $(100,200,400,600$, $800,1000,2000 \mathrm{mg}$ ) exerted any mortality, morbidity or any kind of unwanted changes in behavior during the 8 h observation period.

\section{Phytochemical screening}

The phytochemical screening of EETI revealed that it possessed alkaloids, phenols, terpenoids, carbohydrates, flavonoids, steroids, saponins. The test also indicated the absence of glycosides, cardiac glycosides, tannins, and phlobatanins. The findings are summarized in Table 1.

\section{Analgesic activity}

\section{Formalin-induced paw licking test}

The results of the experiment exhibited that both 200 and $400 \mathrm{mg} / \mathrm{kg}$ doses of EETI showed highly significant $(p<$ 0.001 ) percent inhibition of writhing in both neurogenic phase $(42.40 \%$ and $63.25 \%$ respectively) and inflammatory phase $(41.09 \%$ and $48.63 \%$ respectively) while standard drug Diclofenac sodium showed $73.67 \%$ and $66.56 \%$ in both phases respectively. The analgesic activity exerted by EETI was found highly significant $(p<0.001)$ compared to control and presented in Table 2.

\section{Acetic acid-induced writhing test}

EETI showed highly significant $(p<0.001)$ percent inhibition of writhing in Acetic acid-induced writhing test compared to control. Both the doses of EETI (200 and $400 \mathrm{mg} / \mathrm{kg}$ ) exhibited 57.53 and $62.54 \%$ inhibition of writhing respectively where Diclofenac sodium $(10 \mathrm{mg} /$ $\mathrm{kg}$ ) showed $63.01 \%$. This confirms the significant analgesic activity of EETI. Table 3 represents the results of the test.

\section{Anti-inflammatory activity Carrageen induced paw edema}

The results of the experiment using Carrageenaninduced paw edema to evaluate anti-inflammatory effect of EETI are presented in Table 4. Both the doses $(200$ and $400 \mathrm{mg} / \mathrm{kg})$ of EETI exerted marked $(p<0.01)$ antiinflammatory potential. The percent inhibition of paw volume is presented in Fig. 1. However, maximum $60.90 \%$ of inhibition was showed by $400 \mathrm{mg} / \mathrm{kg}$ dose of EETI at the $3 \mathrm{~h}$, while Diclofenac sodium $(10 \mathrm{mg} / \mathrm{kg})$ showed $75.60 \%$ inhibition at the same time period compared to control.

\section{Antipyretic activity \\ Brewer's yeast-induced pyrexia}

Hyperthermia, induced by yeast, was markedly $(p<0.01)$ lessened by the EETI compared to control. Table 5 showed the results which indicated that the percent inhibition was dose-dependent and remained significant up to $3 \mathrm{~h}$ of administration. The maximum antipyretic effect $77.51 \%$ was observed at $400 \mathrm{mg} / \mathrm{kg}$ while the standard drug Paracetamol $(150 \mathrm{mg} / \mathrm{kg}$ ) showed $90.33 \%$ inhibition. The percent inhibition results are presented in Fig. 2.

\section{Cytotoxic activity}

In brine shrimp lethality bioassay, the EETI exhibited an optimistic result in comparison with the positive control vincristine sulphate. By plotting the concentration versus percentage of mortality for all test samples showed an approximate linear correlation. From the graph, the median lethal concentration $\left(\mathrm{LC}_{50}\right)$ was calculated. Cytotoxic effect of the extract was summarized in Fig. 3. The $\mathrm{LC}_{50}$ for the EETI was found $114.46 \mu \mathrm{g} / \mathrm{mL}$ respectively, and that of the standard VS was $0.56 \mu \mathrm{g} / \mathrm{mL}$. DMSO was used as negative control for validating this method. 
Table 1 Observation and results of phytochemical screening

\begin{tabular}{|c|c|c|c|}
\hline $\begin{array}{l}\text { Secondary } \\
\text { metabolite }\end{array}$ & Name of the test & Observation & Result \\
\hline \multirow[t]{3}{*}{ Alkaloids } & 1. Mayer's test & $\begin{array}{l}\text { White or creamy white } \\
\text { precipitate }\end{array}$ & +++ \\
\hline & 2. Hager's test & $\begin{array}{l}\text { Yellow crystalline } \\
\text { precipitate }\end{array}$ & +++ \\
\hline & 3. Wagner's test & $\begin{array}{l}\text { Brown or deep brown } \\
\text { precipitate }\end{array}$ & +++ \\
\hline Glycosides & General test & No yellow color & - \\
\hline \multirow{2}{*}{$\begin{array}{l}\text { Cardiac } \\
\text { glycosides }\end{array}$} & 1. Legal's test & No pink or red color & - \\
\hline & 2. Baljet's test & $\begin{array}{l}\text { No yellow orange } \\
\text { color }\end{array}$ & - \\
\hline Phenolics & $\mathrm{FeCl}_{3}$ test & Violet color & +++ \\
\hline Terpenoids & Salkowsky test & Reddish color & +++ \\
\hline \multirow[t]{2}{*}{ Carbohydrates } & 1. Molisch Test & $\begin{array}{l}\text { Red-violet layer at the } \\
\text { interface between the } \\
\text { acid (bottom) and } \\
\text { aqueous (upper) layers }\end{array}$ & +++ \\
\hline & 2. Fehling's Test & Red precipitate & +++ \\
\hline \multirow[t]{2}{*}{ Flavonoids } & 1. General test & A yellow colouration & +++ \\
\hline & 2. Specific test & Orange to red color & +++ \\
\hline Steroids & $\begin{array}{l}\text { Libermann- } \\
\text { Burchard's test }\end{array}$ & Greenish color & +++ \\
\hline Tannins & $\mathrm{FeCl}_{3}$ test & $\begin{array}{l}\text { No brownish green } \\
\text { color }\end{array}$ & - \\
\hline Saponins & Frothing test & Change is observed & +++ \\
\hline Phlobatanins & General test & $\begin{array}{l}\text { No Red precipitate } \\
\text { formation }\end{array}$ & - \\
\hline
\end{tabular}

N.B. " +++" stands for the presence and "--" indicates the absence of secondary metabolites

\section{In silico pass prediction}

A total of 10 phytoconstituents namely betulinic acid, catsanogenin, quercetin-3- $\alpha$-arabinoside, chantrieroside A, taccasuboside D, n-triacontanol, taccabulin A, taccalonolide $\mathrm{AA}$, taccalonolide $\mathrm{AB}$, taccalonolide $\mathrm{Z}$ were screened for the antineoplastic (breast cancer) and antinociceptive effects by the aid of the PASS program and the results were used in a resilient manner. The selected compounds exhibited higher $\mathrm{P}_{\mathrm{a}}$ than $\mathrm{P}_{\mathrm{i}}$ (Table 6). The compounds betulinic acid and catsanogenin showed
Table 3 Effect of EETI on acetic acid induced writhing test

\begin{tabular}{llll}
\hline Group & Dose $(\mathrm{mg} / \mathrm{kg})$ & No. of writhing & \% Inhibition \\
\hline Control & - & $43.80 \pm 0.97$ & - \\
Diclofenac sodium & 10 & $16.20 \pm 0.86^{* * *}$ & 63.01 \\
EETI & 200 & $18.60 \pm 0.51^{* * *}$ & 57.53 \\
EETI & 400 & $16.41 \pm 0.39^{* * *}$ & 62.54 \\
\hline
\end{tabular}

SEM standard error of mean, $n=5$, where $\mathrm{n}$ is the number of mice. Values in the figure are expressed as mean $\pm \mathrm{SEM},{ }^{*} p<0.05$, ${ }^{* *} p<0.01$, ${ }^{* * *} p<0.001$ significantly different in comparison with control. The data was analyzed by ANOVA followed by Dunnett's test

highest $\mathrm{P}_{\mathrm{a}}$ value for both antineoplastic activities for breast cancer and antinociceptive activity (Table 6). Quercetin-3- $\alpha$-arabinoside has exhibited a considerable pharmacological activity for breast cancer $\left(P_{a}=0.628\right)$.

\section{In silico molecular docking analysis}

At present, computational techniques have been effectively used for the prediction of drug-target binding affinity and to understand the possible molecular mechanism of the pharmacological responses. Keeping this in view, in silico molecular docking study between ligands and protein were performed to understand comprehensibly that mechanisms and to confirm their findings with the experimental results. In this study, 10 major compounds of $T$. integrifolia were tested against the target enzymes (Human estrogen receptor alpha, PDB ID: 3ERT) and the docking scores obtained for the best-ranked pose for all compounds have been reported in Table 7 .

The best pose found for betulinic acid in the enzymatic pocket of Human estrogen receptor alpha was stabilized by the formation of two hydrogen bonds (H-bonds) with Glu380 and Leu536 with a docking score -4.599 $\mathrm{Kcal} / \mathrm{mol}$ as shown in Fig. 4. Additionally, Catsanogenin binds to the enzymatic pocket of the Human estrogen receptor alpha by forming a series of $\mathrm{H}$-bonds with Glu380, Cys530, Met528 residues (docking score: $4.814 \mathrm{Kcal} / \mathrm{mol}$ ), while Quercetin-3- $\alpha$-arabinoside interacted with the same enzymatic pocket by establishing 3 H-bonds with Met522, Asp351, and Val534 (docking score: $-6.511 \mathrm{Kcal} / \mathrm{mol})$. On the other hand, the remaining phytocompounds didn't show any interactions

Table 2 Effect of EETI on formalin induced writhing effect in mice

\begin{tabular}{lllll}
\hline Groups & Dose mg/kg BW & $\begin{array}{l}\text { Mean } \pm \text { SEM } \\
\text { (\% Writhing) } \\
\text { 1st phase (0-5 min) }\end{array}$ & $\begin{array}{l}\text { \%inhibition 1st } \\
\text { phase (0-5 min) }\end{array}$ & $\begin{array}{l}\text { Mean } \pm \text { SEM (\%Writhing) } \\
\text { last phase (15-30 min) } \\
\text { phase (15-30 min) }\end{array}$ \\
\hline Control & - & $56.6 \pm 0.93$ & - & $40.4 \pm 1.03$ \\
Diclofenac sodium & 10 & $14.90 \pm 0.81^{* * *}$ & 73.67 & $13.60 \pm 0.51^{* * *}$ \\
EETI & 200 & $32.6 \pm 0.24^{* * *}$ & 42.40 & $23.80 \pm 0.20^{* * *}$ \\
EETI & 400 & $20.8 \pm 0.86^{* *}$ & 63.25 & $20.75 \pm 0.72^{* * *}$ \\
\hline
\end{tabular}

SEM standard error of mean, $n=5$, where $\mathrm{n}$ is the number of mice, $\%$ percentage. Values in the table are expressed as mean \pm SEM, ${ }^{*} p<0.05,{ }^{* *} p<0.01,{ }^{* * *} p<$ 0.001 significantly different in comparison with control 
Table 4 Effect of EETI on carrageenan-induced paw edema test

\begin{tabular}{lllllll}
\hline Group & Dose $(\mathrm{mg} / \mathrm{kg})$ & $0 \mathrm{~h}$ & $1 \mathrm{~h}$ & $2 \mathrm{~h}$ & $3 \mathrm{~h}$ & $4 \mathrm{~h}$ \\
\hline Control & $10 \mathrm{~mL}$ & $0.2161 \pm 0.23$ & $0.2181 \pm 0.11$ & $0.2196 \pm 0.19$ & $0.2041 \pm 0.13$ & $0.2039 \pm 0.17$ \\
Diclofenac sodium & 10 & $0.2179 \pm 0.24$ & $0.1486 \pm 0.03^{*}$ & $0.0981 \pm 0.09^{* *}$ & $0.0498 \pm 0.04^{* *}$ & $0.0622 \pm 0.03^{* *}$ \\
EETI & 200 & $0.2141 \pm 0.22$ & $0.2021 \pm 0.10$ & $0.1903 \pm 0.18$ & $0.1498 \pm 0.36^{*}$ & $0.1581 \pm 0.15$ \\
EETI & 400 & $0.2191 \pm 0.21$ & $0.1681 \pm 0.28^{*}$ & $0.1246 \pm 0.31^{*}$ & $0.0797 \pm 0.18^{* *}$ & $0.0941 \pm 0.38^{* *}$
\end{tabular}

SEM standard error of mean, $n=5$. Values in the table are expressed as mean \pm SEM, ${ }^{*} p<0.05,{ }^{* *} p<0.01$ significantly different in comparison with control. The data was analyzed by ANOVA followed by Dunnett's test

with Human estrogen receptor alpha for cytotoxic activity.

\section{ADME/T property analysis}

\section{Ligand based ADME/toxicity prediction}

The drug similar attitude of the ligand molecule was determined using ADME properties by QikProp module of Schrodinger Maestro v10.1. The ADME/T properties of betulinic acid, quercetin- 3 - $\alpha$-arabinoside and catsanogenin were determined with QikProp module of Schrodinger, shown in Table 8. The selected properties are known to affect the cell permeation, metabolism, and bioavailability. Predicted properties of betulinic acid were in the range for satisfying the Lipinski's rule of five to be recognized as drug-like potential. Betulinic acid and catsanogenin possessed a higher rate of human oral absorption.

\section{Discussion}

To evaluate both central and peripheral analgesic activity along with the antipyretic activity of EETI formalininduced paw licking test, acetic acid-induced writhing test and Brewer's yeast-induced pyrexia test were conducted respectively. Formalin-induced paw licking test is an established method for evaluating central analgesic activity. In this test, two distinguishable different stimuli involve and thus the animals exhibits two phases of pain actions [30]. The early phase may include the nociceptors and the direct action of formalin in it and centrally acting analgesics suppress it. On the contrary, the late phase occurs as a result of the inflammation which is mediated by different inflammatory mediators like prostaglandins, bradykinin or histamine and subdued by centrally acting analgesics, sometimes with steroids and sometimes by non-steroidal anti-inflammatory drugs (NSAIDs). In this study, both in neurogenic phase and inflammatory phase, the two doses $200 \mathrm{mg} / \mathrm{kg}$ and 400 $\mathrm{mg} / \mathrm{kg}$, EETI produced highly significant $(p<0.001)$ effects in the formalin test. That means the plant extracts may pose its analgesic activity by centrally acting or peripheral mechanisms. This observed analgesic activity may be as a result of phytochemicals presents in the extracts [31].

Out of several different modes to select administrative doses for animal models, selection based on acute toxicity-test and $\mathrm{LD}_{50}$ value is our prime choice. According to the theory, prior to intervention, a group of animals is received a gradually increased dose to apprehend a toxic dose which leads to calculate $\mathrm{LD}_{50}$. The effective therapeutic dose was taken as one tenth of the median lethal dose $\left(\mathrm{LD}_{50}>2.0 \mathrm{~g} / \mathrm{kg}\right)$ [32] which is practically justified using a logarithmically linked dose. Additionally, the reference control is a pure single molecule drug which is established as $10 \mathrm{mg} / \mathrm{kg} \mathrm{BW}$ for its

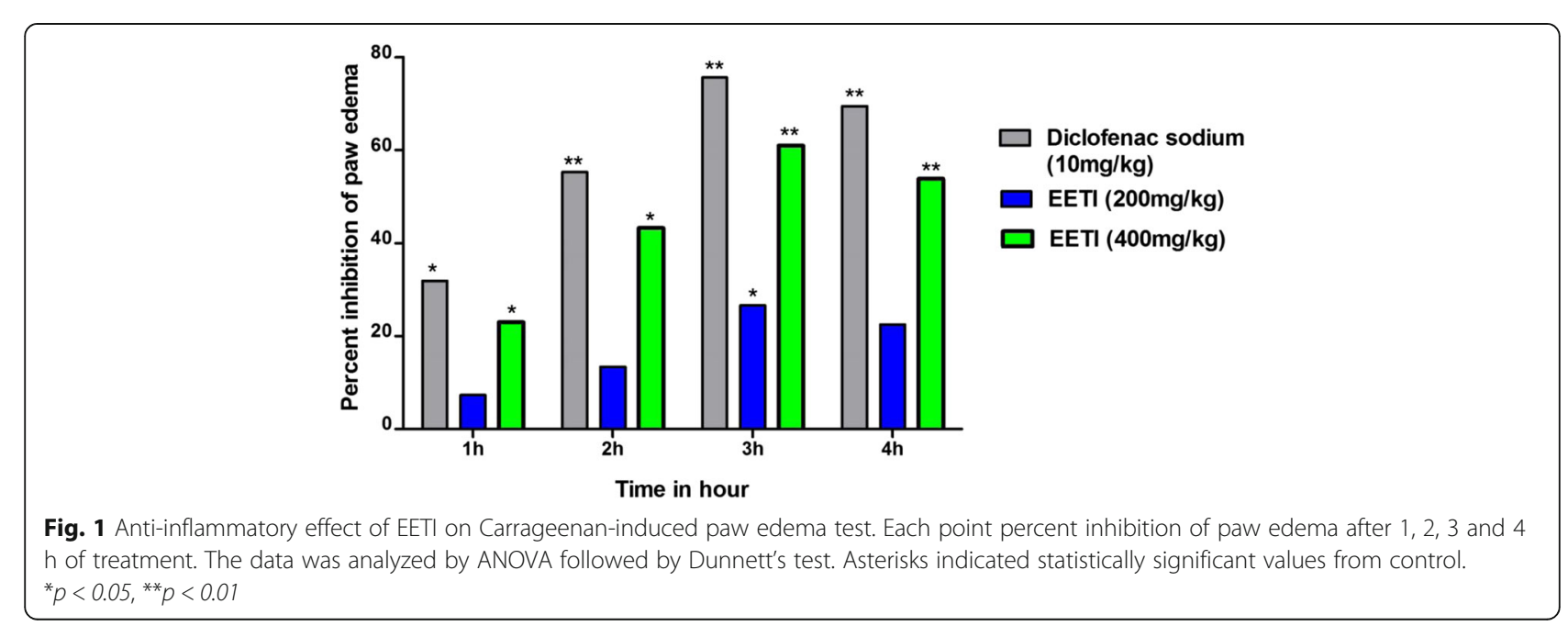


Table 5 Effect of EETI on Yeast-induced pyrexia in mice

\begin{tabular}{|c|c|c|c|c|c|c|c|}
\hline \multirow[t]{3}{*}{ Groups } & \multirow{3}{*}{$\begin{array}{l}\text { Dose } \\
\text { (mg/ } \\
\mathrm{kg})\end{array}$} & \multicolumn{6}{|c|}{ Rectal temperature $\left({ }^{\circ} \mathrm{C}\right)$} \\
\hline & & \multirow{2}{*}{$\begin{array}{l}\text { Normal (A) } \\
\text { (Before } \\
\text { yeast } \\
\text { injection) }\end{array}$} & \multicolumn{5}{|c|}{ After administration of drug } \\
\hline & & & after $24 \mathrm{~h}$ (B) & 1st h (C1) & 2nd h (C2) & $3 r d h(C 3)$ & 4th h (C4) \\
\hline Control & $10 \mathrm{~mL}$ & $36.65 \pm 0.10$ & $38.91 \pm 0.33$ & $38.81 \pm 0.20$ & $38.77 \pm 0.10$ & $38.67 \pm 0.19$ & $38.68 \pm 0.20$ \\
\hline Paracetamol & 150 & $37.07 \pm 0.07$ & $39.45 \pm 0.06$ & $38.19 \pm 0.02^{* *}$ & $37.82 \pm 0.05^{* *}$ & $37.30 \pm 0.01^{* *}$ & $37.34 \pm 0.27^{* *}$ \\
\hline EETI & 200 & $37.04 \pm 0.05$ & $39.72 \pm 0.45$ & $39.42 \pm 0.25$ & $38.98 \pm 0.21^{*}$ & $38.02 \pm 0.12^{* *}$ & $38.03 \pm 0.14^{* *}$ \\
\hline EETI & 400 & $37.02 \pm 0.10$ & $39.82 \pm 0.21$ & $39.32 \pm 0.33$ & $38.72 \pm 0.13^{*}$ & $37.65 \pm 0.45^{* *}$ & $37.72 \pm 0.11^{* *}$ \\
\hline
\end{tabular}

SEM standard error of mean, $n=5$, where $\mathrm{n}$ is the number of mice. Values in the figure are expressed as mean \pm SEM, ${ }^{*} p<0.05,{ }^{* *} p<0.01$ significantly different in comparison with control. The data was analyzed by ANOVA followed by Dunnett's test

effectiveness. On the contrary, the crude extract is usually reported to have relatively lower absorption that is harmonized with it $\mathrm{LD}_{50}$ based relatively higher doses. Indeed, ethanol is no doubt a very good solvent for polyphenols and flavonoids extraction and is safe for human consumption [33, 34]. Our target was to collect the polyphenols-rich extract probably having the target biological effects $[35,36]$ designed for this research. Methanol has been avoided as it is generally found to be more efficient in extraction of lower molecular weight polyphenols which suffers from our target.

The peripheral analgesic activity is determined by the administration of vicious chemicals such as acetic acid intraperitoneally which resulting writhing response of mouse [37]. Several inflammatory mediators e.g. prostaglandins, histamine and bradykinin are induced by the intraperitoneal administration of acetic acid thus stimulating pain sensation $[38,39]$. At the time of the writhing test, the level of prostaglandins, especially PGE2 and PGF $2 \alpha$ and also the lipoxygenase products in the peritoneal fluids are markedly raised [40, 41]. Analgesic activity is possessed by the extracts if the extracts are able to recede the acetic acid-induced writhing in mice. In our observation, EETI showed highly significant $(p<$
0.001) percent inhibition of writhing in the acetic acidinduced writhing test. The EETI of the plant might be hindered the biosynthesis, release and/or action of the chemical agent like prostaglandins and leukotrienes from cyclo-oxygenase and lipo-oxygenase pathways, respectively and thus exhibiting analgesic property by inhibiting the pain sensation. The presence of alkaloids may avail this analgesic activity [42].

Carrageenan-induced paw edema test is a wellestablished and most widely used test to evaluate the anti-inflammatory potential of plants and drugs [43, 44]. Inflammation is a complex process as it involves the activation of various mediators like prostaglandins, kinins, platelet activating factors, leukotrienes, neutrophils and several cytokines including interleukins and tumor necrosis factors [45]. These mediators play an important role in the development of edema [46]. The administration of carrageenan gives the rise of bradykinin along with prostaglandin and other autacoids. Neutrophils and free radicals like hydrogen peroxide, superoxide, and hydroxyl radicals are also released by the carrageenan and play a significant role in the formation of edema [47, 48]. However, Carrageenan-induced paw edema is a biphasic event. The release of kinins, serotonin, and

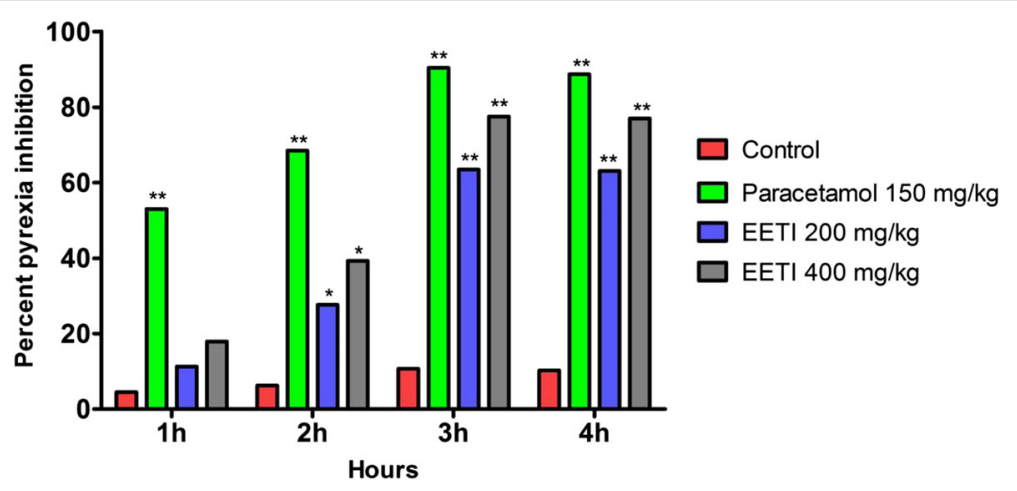

Fig. 2 Antipyretic effect of EETI in mice. Bar presents the percent inhibition of pyrexia after 1, 2, 3 and $4 \mathrm{~h}$ of the treatment with Paracetamol $(150 \mathrm{mg} / \mathrm{kg})$ and EETI $(200$ and $400 \mathrm{mg} / \mathrm{kg}) .{ }^{*} p<0.05,{ }^{* *} p<0.01$, significantly different in comparison with control. The data was analyzed by ANOVA followed by Dunnett's test 


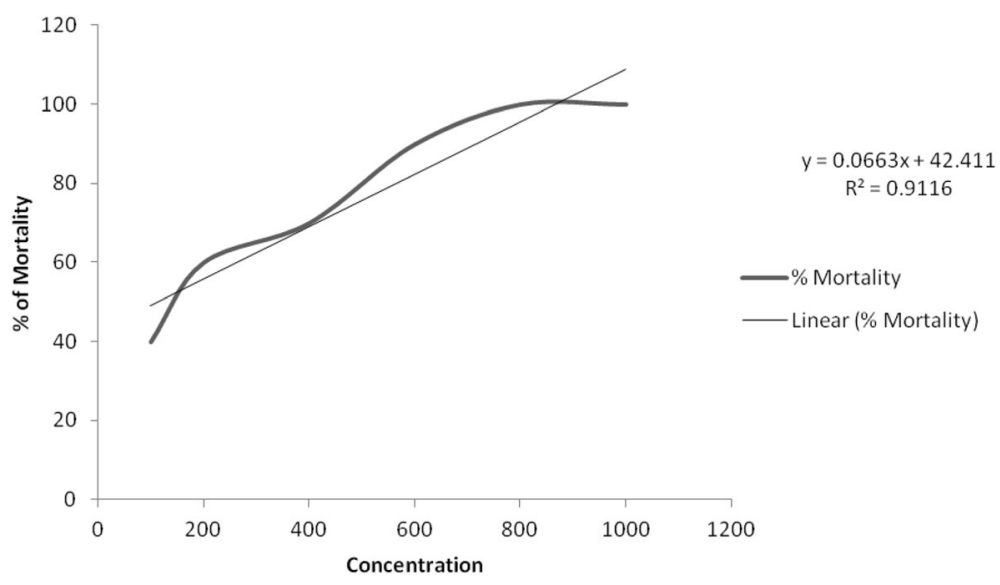

Fig. 3 Cytotoxic effect of EETI in brine shrimp nauplii . Effects of various concentrations of ethanol extract of T. integrifolia rhizomes on the viability of brine shrimp nauplii after $24 \mathrm{~h}$ incubation. Percentage mortality of brine shrimps of ethanolic extract of rhizomes of $T$. integrifolia. Data are shown as mean \pm SEM of 10 shrimps for each concentration

histamine occurs in the initial phase whereas prostaglandins, lysosomes and protease are released in the later phase. This later phase is sensitive to most clinically effective anti-inflammatory drugs [49]. The results of the current study showed that EETI possessed marked antiinflammatory potential as its $400 \mathrm{mg} / \mathrm{kg}$ dose significantly inhibited inflammation (From a 2nd hour and onwards) induced by carrageenan injection. This indicated that EETI probably inhibited either cyclooxygenase and/ or lipo-oxygenase enzyme or the synthesis, release, and action of above inflammatory mediators.

Pyrexia is inclined by subcutaneous injection of Brewer's yeast as it uplifts the prostaglandin synthesis and considered as an important test for the identification of antipyretic effect on several plant materials and other synthetic drugs $[19,50]$. Yeast-induced pyrexia is known as pathogenic fever which causes the synthesis of prostaglandins [51]. Obstruction of cyclo-oxygenase pathways leads to the curbing of prostaglandins and might be a possible mechanism of antipyretic activity as that of several non-steroidal anti-inflammatory drugs (NSAIDs). Blocking of different mediators for pyrexia are responsible for the antipyretic effect [52]. In this experiment, the intraperitoneal administration of EETI markedly $(p<0.01)$ lessened the yeast-induced hyperthermia in the feverish mice. Thus it can be presumed that EETI has certain pharmacologically active components which are responsible for the interference with the release of prostaglandins and by this way, reducing the body temperature.

Plant material toxicity is an important concernment for researchers and scientists [53-56]. Due to this purpose, the cytotoxicity assay was performed in this study for the determination of toxicity profile of the EETI using brine shrimp lethality bioassay. According to Meyer et al. 1982, crude extracts and pure substances

Table 6 Pass prediction of betulinic acid, catsanogenin, quercetin-3-a-arabinoside, chantrieroside A, taccasuboside D, n-triacontanol, taccabulin A, taccalonolide AA, taccalonolide AB, taccalonolide $Z$ for antineoplastic (breast cancer) and antinociceptive activity

\begin{tabular}{|c|c|c|c|c|}
\hline \multirow[t]{2}{*}{ Compounds } & \multicolumn{2}{|c|}{ Pass prediction of antineoplastic (breast cancer) activity } & \multicolumn{2}{|c|}{ Pass prediction of antinociceptive activity } \\
\hline & $\mathrm{Pa}$ & $\mathrm{Pi}$ & $\mathrm{Pa}$ & $\mathrm{Pi}$ \\
\hline Betulinic acid & 0.723 & 0.005 & 0.768 & 0.002 \\
\hline Catsanogenin & 0.510 & 0.018 & 0.790 & 0.002 \\
\hline Quercetin-3-a-arabinoside & 0.628 & 0.009 & 0.352 & 0.144 \\
\hline Chantrieroside A & 0.559 & 0.014 & 0.445 & 0.075 \\
\hline Taccasuboside D & 0.389 & 0.033 & 0.591 & 0.009 \\
\hline n-triacontanol & - & - & 0.509 & 0.031 \\
\hline Taccabulin A & 0.349 & 0.042 & 0.413 & 0.099 \\
\hline Taccalonolide AA & 0.408 & 0.030 & - & - \\
\hline Taccalonolide AB & 0.475 & 0.022 & - & - \\
\hline Taccalonolide Z & 0.475 & 0.024 & - & - \\
\hline
\end{tabular}


Table 7 Docking result of betulinic acid, catsanogenin and quercetin-3-a-arabinoside with estrogen receptor alpha (ER-a) (PDB: 3ERT) in $\mathrm{kcal} / \mathrm{mol}$

\begin{tabular}{llll}
\hline Compound name & Docking score & Glide e model & Glide energy \\
\hline Betulinic acid & -4.129 & -47.916 & -37.828 \\
Catsanogenin & -4.604 & -52.085 & -41.136 \\
Quercetin-3-a-arabinoside & -6.286 & -68.354 & -49.43 \\
Chantrieroside A & - & - & - \\
Taccasuboside D & - & - & - \\
n-triacontanol & - & - & - \\
Taccabulin A & - & - & - \\
Taccalonolide AA & - & - & - \\
Taccalonolide AB & - & - & - \\
Taccalonolide Z & - & - & - \\
\hline
\end{tabular}

are toxic if the $\mathrm{LC}_{50}$ value is less than $1000 \mu \mathrm{g} / \mathrm{mL}$ and non-toxic if the value of $\mathrm{LC}_{50}$ is greater than $1000 \mu \mathrm{g} /$ $\mathrm{mL}$. In this experiment, the $\mathrm{LC}_{50}$ value for the EETI of T. integrifolia was found $114.46 \mu \mathrm{g} / \mathrm{mL}$ respectively and hence the outcome demonstrated that the rhizome extract is cytotoxic. Further investigation and literature survey prove that the rhizome extract contains some cytotoxic compounds.

In the purpose of accelerating the potent natural product research, computer-aided drug discovery (CADD) program PASS was used for the biological activity prediction. Pass prediction tool was consists of using 20,000 principal compounds [57]. The results of the prediction were demonstrated as $\mathrm{P}_{\mathrm{a}}$ and $\mathrm{P}_{\mathrm{i}}$ ratio. In this experiment, betulinic acid and catsanogenin have shown the maximum $\mathrm{P}_{\mathrm{a}}$ value for both antineoplastic and analgesic activities. Quercetin-3- $\alpha$-arabinoside possessed a higher rate of antineoplastic activity against breast cancer showing the $\mathrm{P}_{\mathrm{a}}$ value of 0.628 . Among the 10 compounds our

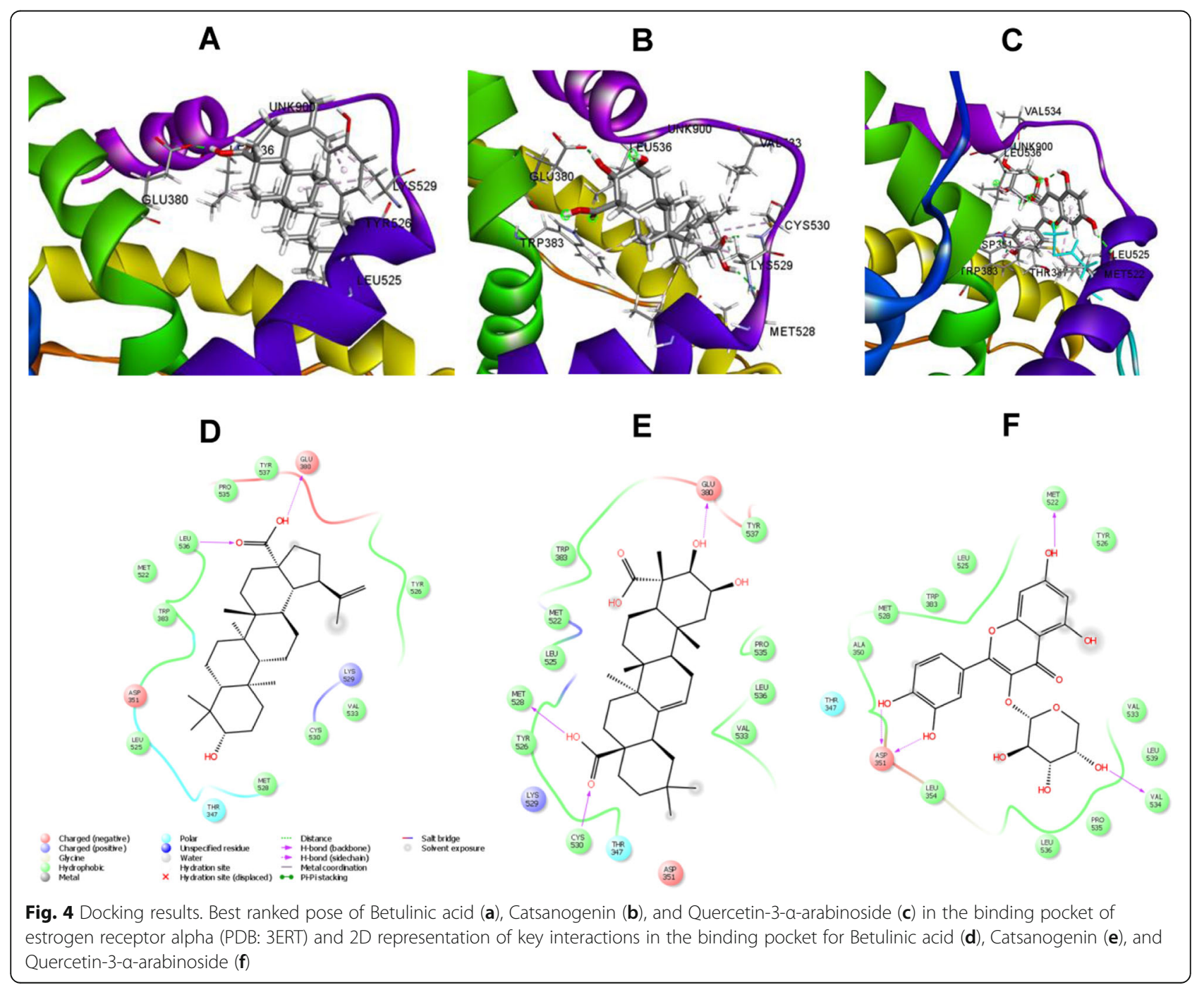


Table 8 ADME and drug likeness properties of betulinic acid, quercetin-3-a-arabinoside and catsanogenin by QikProp

\begin{tabular}{|c|c|c|c|c|c|c|c|c|}
\hline Compound name & $\mathrm{MW}^{\mathrm{a}}$ & $\mathrm{HB}$ donor ${ }^{\mathrm{b}}$ & HB acceptor ${ }^{c}$ & SASA & QPlogPo/we & $\mathrm{QPlogBB}^{\mathrm{f}}$ & QPlogS $^{9}$ & $\begin{array}{l}\text { \%Human Oral } \\
\text { Absorption }^{\text {h }}\end{array}$ \\
\hline Betulinic acid & 456.707 & 2 & 3.7 & 683.818 & 6.2 & -0.403 & -6.712 & 95.647 \\
\hline Catsanogenin & 502.69 & 3 & 6.4 & 724.914 & 5.103 & -1.585 & -6.276 & 45.093 \\
\hline Quercetin-3-a-arabinoside & 434.356 & 6 & 12.05 & 631.252 & -0.807 & -2.669 & -4.134 & 13.443 \\
\hline
\end{tabular}

${ }^{\mathrm{a}}$ Molecular weight (acceptable range: $<500$ ). ${ }^{\mathrm{b}} \mathrm{Hydrogen}$ bond donor (acceptable range: $\leq 5$ ). ${ }^{\mathrm{c}}$ Hydrogen bond acceptor (acceptable range: $\leq 10$ ). ${ }^{\mathrm{d}}$ Total Solvent Accessible Surface Area in using a probe with a 1.4 radius (acceptable range: 300-1000). ${ }^{~}$ Predicted octanol/water partition coefficient (acceptable range: - 2-6.5). fPredicted blood-brain partition co-efficient (acceptable range: -3-1.2). ${ }^{9}$ Predicted aqueous solubility, $\mathrm{S}$ in $\mathrm{mol} / \mathrm{dm}^{-3}$ (acceptable range: $\left.-6.5-0.5\right)$. ${ }^{\mathrm{h}}$ Predicted human oral absorption on 0 to $100 \%$ scale $(<25 \%$ is poor and $>80 \%$ is high)

docking study suggests that betulinic acid, catsanogenin, and quercetin-3- $\alpha$-arabinoside may be the responsible bioactive phytochemicals for potential cytotoxic or anticancer activities of the plant. According to the Glide Docking score and Glide energy we can see that among these three compounds quercetin-3- $\alpha$-arabinoside is the potent compound, although further in vivo studies are needed to explore their in-depth mechanism of action. This finding is also consistent with the literature data since an earlier report stated that both compounds (betulinic acid and quercetin-3- $\alpha$-arabinoside) have anticancer properties.

Breast cancer is the most common tumor for cancer progression in the industrialized countries and it is one of the most important reasons for cancerrelated mortality [58]. Tumor expression of estrogen receptors (ERs) predicts the response to treatment of breast cancer as estrogen is concerned physiologically with a greater risk for breast and endometrial cancer [59]. The change of activity of ERs induces cancer regression especially estrogen receptor alpha (ER- $\alpha)$ [60]. ER- $\alpha$ is a carping regulatory gene for the improvement of the breast cancer and its expression is crucial for tumor progression. In this study, components from the rhizome of plant $T$. integrifolia i.e. betulinic acid, catsanogenin, quercetin-3- $\alpha$-arabinoside were investigated for the interaction with estrogen alpha receptor ligand binding domain. All the compounds possessed a higher attraction towards the ligand binding domain of estrogen alpha receptor and the blockade may be due to strong ligand-protein complex formation. The compound quercetin-3- $\alpha$-arabinoside showed highest docking score of -6.286 $\mathrm{kcal} / \mathrm{mol}$. For natural product chemists, the necessity of virtual screening is significant for the quest of active principles with attractive ADME/T profiles which have been separated before but not analyzed for activity against specific drug targets [22]. The ADME and toxicity profiles of the compounds betulinic acid, catsanogenin, quercetin-3- $\alpha$-arabinoside are moderate and they are thought to be potential drug in terms of better pharmacokinetic parameters with the less amount of toxicity.

\section{Conclusions}

The investigation indicated that EETI is safe to show significant analgesic activity and moderate anti-inflammatory, and antipyretic activity. However, the extract is cytotoxic to the brine shrimps naupliis. Moreover, from the in silico PASS prediction, the isolated phytoconstituents are greatly impacted for analgesic and anticancer activity against breast cancer. But, quercetin-3- $\alpha$-arabinoside could be chosen based for its best fitness score and betulinic acid seems the highest capability to be absorbed upon oral administration.

\section{Abbreviations \\ ADME: Absorption, distribution, metabolism, and excretion; BW: Body weight; CADD: Computer-aided drug discovery; EETI: Ethanolic extract of Tacca integrifolia rhizome; ER-a: Estrogen receptor alpha; $\mathrm{LC}_{50}$ : Lethal concentration; i.p: intraperitoneal; NSAIDs: Non-steroidal anti-inflammatory drugs; PASS: Predict the activity spectra for substances; s.c: subcutaneous; VS: Vincristine sulphate}

\section{Acknowledgements}

The authors are grateful to the Department of Pharmacy, Faculty of Biological Sciences, University of Chittagong, Chittagong-4331, Bangladesh, for providing the facilities to conduct this research work. The authors are also thankful to the Taxonomist and Professor, Dr. Shaikh Bokhtear Uddin, Department of Botany, University of Chittagong, Bangladesh, for identifying all the plants.

\section{Declarations}

All authors read the manuscript and approved it for submission. No part of the manuscript has been published before, nor is any part of it under consideration for publication at another journal.

\section{Authors' contributions}

This work was carried out in collaboration between all authors. All the authors have accepted responsibility for the entire content of this submitted manuscript and approved submission. Authors SA and AR collected the plant leaves and prepared the extracts and fractions. SA, AR, MAI, BHK and FBF carried out the study design, performed the experiments, data collection, data interpretation, manuscript preparation, statistical analysis. Authors AP, MNUC and SMAU has arranged the in silico docking study. NMMAB, MMNU, MAR, and TBE designed and planned the studies, supervised the experiments. TBE also acted for all correspondences. TBE and MAR participated in the manuscript draft and has thoroughly checked and revised the manuscript for necessary changes in format, grammar and English standard. All authors read and approved the final version of the manuscript.

\section{Funding}

This work is managed to perform with the individual funding of all authors. 


\section{Ethics approval and consent to participate}

This study was approved by ethical research committee of the Faculty of Biological Science of the University of Chittagong, Bangladesh (AERB/FBS/ UC/02, 2015).

\section{Consent for publication}

Not applicable.

\section{Competing interests}

The authors declare that they have no competing interests.

\section{Author details}

'Department of Pharmacy, Faculty of Biological Science, University of Chittagong, Chittagong 4331, Bangladesh. ${ }^{2}$ Drug Discovery, GUSTO A Research Group, Chittagong 4000," Bangladesh. ${ }^{3}$ Department of Microbiology, Jagannath University, Dhaka 1100, Bangladesh. ${ }^{4}$ Department of Pharmacy, International Islamic University Chittagong, Chittagong 4318, Bangladesh. ${ }^{5}$ Department of Pharmacy, Jagannath University, Dhaka 1100" Bangladesh. ${ }^{6}$ Medical Officer, Department of Haematology, Chittagong Medical College Hospital, Chittagong 4000, Bangladesh. ${ }^{7}$ Department of Biochemistry and Molecular Biology, University of Chittagong, Chittagong 4331 „Bangladesh. ${ }^{8}$ Department of Pharmacy, BGC Trust University Bangladesh, Chandanaish, Chittagong 4381 „Bangladesh.

Received: 16 April 2019 Accepted: 9 October 2019 Published online: 15 November 2019

\section{References}

1. Weng X, Smith T, Sathish J, Djouhri L. Chronic inflammatory pain is associated with increased excitability and hyperpolarization-activated current (Ih) in C- but not Ad-nociceptors. Pain ${ }^{\circledR}$. 2012;153(4):900-14.

2. Adnan MSA, Al-Amin MM, Uddin MMN, Shohel M, Bhattacharjee R, Hannan J, Das BK. Analgesic, anti-inflammatory and antipyretic effects of Ixora coccinea. J Basic Clin Physiol Pharmacol. 2014;25(4):423-8.

3. Zaveri $\mathrm{M}$, Gohil $\mathrm{P}$, Jain S. Immunostimulant activity of n-butanol fraction of root bark of Oroxylum indicum vent. J Immunotoxicol. 2006;3(2):83-99.

4. Mclaughlin JL, Rogers LL, Anderson JE. The use of biological assays to evaluate botanicals. Drug Inf J. 1998;32(2):513-24.

5. Parasuraman S. Prediction of activity spectra for substances. J Pharmacol Pharmacother. 2011;2(1):52.

6. Filimonov D, Lagunin A, Gloriozova T, Rudik A, Druzhilovskii D, Pogodin P, Poroikov $V$. Prediction of the biological activity spectra of organic compounds using the PASS online web resource. Chem Heterocycl Com. 2014:50(3):444-57.

7. Guedes IA, de Magalhães CS, Dardenne LE. Receptor-ligand molecular docking. Biophys Rev. 2014;6(1):75-87.

8. Yusuf M, Begum J, Hoque MN, Choudhury JU. Medicinal plants of Bangladesh-Revised and Enlarged. Chittagong: Bangladesh Coun. Sci. Ind. Res. Lab; 2009.

9. Ghani A. Medicinal plants of Bangladesh: chemical constituents and uses. Dhaka: Asiatic Society of Bangladesh; 1998.

10. Kitjaroennirut $N$, Jansakul C, Sawangchote P. Cardiovascular effects of Tacca integrifolia Ker-Gawl extract in rats. Songklanakarin J Sci Technol. 2005;27(2): 281-9.

11. Razak M-FA, Aidoo KE, Candlish AG. Mutagenic and cytotoxic properties of three herbal plants from Southeast Asia. Trop Biomed. 2007;24(2):49-59.

12. Shwe HH, Aye M, Sein MM, Htay KT, Kreitmeier P, Gertsch J, Reiser O, Heilmann J. Cytotoxic steroidal saponins from the rhizomes of Tacca integrifolia. Chem Biodivers. 2010;7(3):610-22.

13. Haque M, Haque M, Rahman M, Khondkar P. Antibacterial and cytotoxic activities of Capparis zeylanica Linn roots. Ars Pharmaceutica. 2008:49(1):317.

14. Faisal M, Hossain Al, Rahman S, Jahan R, Rahmatullah M. A preliminary report on oral glucose tolerance and antinociceptive activity tests conducted with methanol extract of Xanthosoma violaceum aerial parts. BMC Complement Altern Med. 2014:14(1):335.

15. Ghani A. Medicinal plants of Bangladesh with chemical constituents and uses. vol. 5: Asiatic Society of Bangladesh; Dhaka: Bangladesh; 2003.

16. Santos A, Calixto J. Further evidence for the involvement of tachykinin receptor subtypes in formalin and capsaicin models of pain in mice. Neuropeptides. 1997;31(4):381-9.
17. Santos AR, De Campos RO, Miguel OG, Filho VC, Siani AC, Yunes RA, Calixto JB. Antinociceptive properties of extracts of new species of plants of the genus Phyllanthus (Euphorbiaceae). J Ethnopharmacol. 2000;72(1-2):229-38.

18. Süleyman H, Demirezer LÖ, Kuruüzüm A, Banoğlu Z, Göçer F, Özbakir G, Gepdiremen A. Antiinflammatory effect of the aqueous extract from Rumex patientia L. roots. J Ethnopharmacol. 1999:65(2):141-8.

19. Khan I, Nisar M, Ebad F, Nadeem S, Saeed M, Khan H, Khuda F, Karim N, Ahmad Z. Anti-inflammatory activities of Sieboldogenin from Smilax china Linn.: experimental and computational studies. J Ethnopharmacol. 2009; 121(1):175-7.

20. Kang J, Khan M, Park N, Cho J, Lee M, Fujii H, Hong Y. Antipyretic, analgesic, and anti-inflammatory activities of the seaweed Sargassum fulvellum and Sargassum thunbergii in mice. J Ethnopharmacol. 2008;116(1):187-90.

21. Meyer B, Ferrigni N, Putnam J, Jacobsen L, Nichols D, McLaughlin JL. Brine shrimp: a convenient general bioassay for active plant constituents. Planta Med. 1982;45(5):31-4.

22. Liu ZH, Yan H, Liu HY. Chemical constituents and their bioactivities of plants of Taccaceae. Chem Biodivers. 2015;12(2):221-38.

23. Mojumdar M, Kabir MSH, Hasan MS, Ahmed T, Rahman MR, Akter Y, Rahman MM. Molecular docking and pass prediction for analgesic activity of some isolated compounds from Acalypha indica $L$ and $A D M E / T$ property analysis of the compounds. World J Pharma Res. 2016;5(7):1761-70.

24. Goel RK, Singh D, Lagunin A, Poroikov V. PASS-assisted exploration of new therapeutic potential of natural products. Med Chem Res. 2011;20(9):1509-14.

25. Khurana N, Ishar MPS, Gajbhiye A, Goel RK. PASS assisted prediction and pharmacological evaluation of novel nicotinic analogs for nootropic activity in mice. Eur J Pharmacol. 2011;662(1-3):22-30.

26. Berman HM, Battistuz T, Bhat TN, Bluhm WF, Bourne PE, Burkhardt K, Feng Z, Gilliland GL, lype L, Jain S. The protein data bank. Acta Crystallogr D Bio Crystallogr. 2002:58(6):899-907.

27. Friesner RA, Banks JL, Murphy RB, Halgren TA, Klicic JJ, Mainz DT, Repasky MP, Knoll EH, Shelley M, Perry JK. Glide: a new approach for rapid, accurate docking and scoring. 1. Method and assessment of docking accuracy. J Med Chem. 2004:47(7):1739-49.

28. Friesner RA, Murphy RB, Repasky MP, Frye LL, Greenwood JR, Halgren TA, Sanschagrin PC, Mainz DT. Extra precision glide: docking and scoring incorporating a model of hydrophobic enclosure for protein-ligand complexes. J Med Chem. 2006:49(21):6177-96.

29. Natarajan A, Sugumar S, Bitragunta S, Balasubramanyan N. Molecular docking studies of (4 Z, 12 Z)-cyclopentadeca-4, 12-dienone from Grewia hirsuta with some targets related to type 2 diabetes. BMC Complement Altern Med. 2015;15(1):73.

30. Uddin MMN, Kabir MSH, Hasan M, Al Mahmud Z, Bhuiya NMA, Ahmed F, Hasan MR, Hosen MT, Alam MS. Assessment of the antioxidant, thrombolytic, analgesic, anti-inflammatory, antidepressant and anxiolytic activities of leaf extracts and fractions of Tetracera sarmentosa (L.) Vahl. J Basic Clin Physiol Pharmacol. 2018:29(1):81-93.

31. Zulfiker A, Rahman MM, Hossain MK, Hamid K, Mazumder M, Rana MS. In vivo analgesic activity of ethanolic extracts of two medicinal plants-Scoparia dulcis L. and Ficus racemosa Linn. Biol Med. 2010;2(2):42-8.

32. Zaoui A, Cherrah Y, Mahassini N, Alaoui K, Amarouch H, Hassar M. Acute and chronic toxicity of Nigella sativa fixed oil. Phytomedicine. 2002;9:69-74.

33. Diem Do Q, Angkawijaya AE, Tran-Nguyen PL, Huynh LH, Soetaredjo FE, Ismadji S, Ju YH. Effect of extraction solvent on total phenol content, total flavonoid content, and antioxidant activity of Limnophila aromatica. J Food Drug Anal. 2014;22:296-302.

34. Bonoli M, Verardo V, Marconi E, Caboni MF. Antioxidant phenols in barley (Hordeum vulgare L.) flour: comparative spectrophotometric study among extraction methods of free and bound phenolic compounds. J Agric Food Chem. 2004:52:5195e200.

35. Rajnarayana K, Reddy MS, Chaluvadi MR, Krishna DR. Biflavonoids classification, pharmacological, biochemical effects and therapeutic potential. Indian J Pharmacol. 2001;33:2-16.

36. Tiwari $P$, Kumar B, Kaur M, Kaur G, Kaur H. Phytochemical screening and extraction: a review. Int Pharmaceutica Sciencia. 2011;1(1):98-106.

37. Trongsakul S, Panthong A, Kanjanapothi D, Taesotikul T. The analgesic, antipyretic and anti-inflammatory activity of Diospyros variegata Kruz. J Ethnopharmacol. 2003:85(2-3):221-5.

38. Khan MA, Rahman AA, Nahar L, Islam MB, Alam AHMK. In vivo analgesic and CNS depressant activities of antioxidative stem bark fraction of Morus alba L. Dhaka Univ J Pharm Sci. 2014;13(2):225-7. 
39. Bispo M, Mourão R, Franzotti E, Bomfim K, Arrigoni-Blank MDF, Moreno M, Marchioro M, Antoniolli A. Antinociceptive and antiedematogenic effects of the aqueous extract of Hyptis pectinata leaves in experimental animals. J Ethnopharmacol. 2001;76(1):81-6.

40. Deraedt R, Jouquey S, Delevallée F, Flahaut M. Release of prostaglandins $E$ and $F$ in an algogenic reaction and its inhibition. Eur J Pharmacol. 1980; 61(1):17-24.

41. Dhara A, Suba V, Sen T, Pal S, Chaudhuri AN. Preliminary studies on the antiinflammatory and analgesic activity of the methanolic fraction of the root extract of Tragia involucrata Linn. J Ethnopharmacol. 2000;72(1-2):265-8.

42. Uche F, Aprioku J. The phytochemical constituents, analgesic and antiinflammatory effects of methanol extract of Jatropha curcas leaves in Mice and Wister albino rats. Appl Sci Environ Manage. 2008;12(4):99-102.

43. Uddin MMN, Ahmed S, Kabir MSH, Rahman MS, Sultan RA, Emran TB. In vivo analgesic, anti-inflammatory potential in Swiss albino mice and in vitro thrombolytic activity of hydroalcoholic fruits extract from Daemonorops robusta Warb. J Appl Pharm Sci. 2017;7(1):104-13.

44. Chen Y-F, Tsai H-Y, Wu T-S. Anti-inflammatory and analgesic activities from roots of Angelica pubescens. Planta Med. 1995;61(1):2-8.

45. Roumestan C, Michel A, Bichon F, Portet K, Detoc M, Henriquet C, Jaffuel D, Mathieu M. Anti-inflammatory properties of desipramine and fluoxetine. Respir Res. 2007:8(1):35.

46. Damas J, Remacle-Volon G, Deflandre E. Further studies of the mechanism of counter irritation by turpentine. Naunyn Schmiedebergs Arch Pharmacol. 1986;332(2):196-200.

47. Dawson J, Sedgwick A, Edwards J, Lees P. A comparative study of the cellular, exudative and histological responses to carrageenan, dextran and zymosan in the mouse. Int J Tissue React. 1991;13(4):171-85.

48. Dudhgaonkar SP, Tandan SK, Bhat AS, Jadhav SH, Kumar D. Synergistic antiinflammatory interaction between meloxicam and aminoguanidine hydrochloride in carrageenan-induced acute inflammation in rats. Life Sci. 2006;78(10):1044-8.

49. Vinegar R, Schreiber W, Hugo R. Biphasic development of carrageenin edema in rats. J Pharmacol Exp Ther. 1969;166(1):96-103.

50. Devi BP, Boominathan R, Mandal SC. Evaluation of antipyretic potential of Cleome viscosa Linn. (Capparidaceae) extract in rats. J Ethnopharmacol. 2003:87(1):11-3

51. Moltz H. Fever: causes and consequences. Neurosci Biobehav Rev. 1993; 17(3):237-69.

52. Rawlins M, Postgrad R. Mechanism of salicylate-induced antipyresis. In: Pharmacology Thermoregulatory Proceeding Satellite Symposium; 1973. p. 311-24

53. Rahman MM, Alam AHMK, Sadik G, Islam MR, Proma Khondkar P, Hossain MA, Rashid MA. Antimicrobial and cytotoxic activities of Achyranthes ferruginea. Fitoterapia. 2007;78:260-2.

54. Singh A, Singh SK. Molluscicidal evaluation of three common plants from India. Fitoterapia. 2005;76(7-8):747-51.

55. Fowles RG, Mootoo BS, Ramsewak RS, Khan A. Toxicity-structure activity evaluation of limonoids from Swietenia species on Artemia salina. Pharm Biol. 2012;50(2):264-7.

56. Prasad S, Kashyap RS, Deopujari JY, Purohit HJ, Taori GM, Daginawala HF. Development of an in vitro model to study clot lysis activity of thrombolytic drugs. Thromb J. 2006;4(1):14

57. Shao W, Brown M. Advances in estrogen receptor biology: prospects for improvements in targeted breast cancer therapy. Breast Cancer Res. 2003;6(1):39

58. McDonnell DP, Norris JD. Connections and regulation of the human estrogen receptor. Science. 2002;296(5573):1642-4.

59. Ntie-Kang F, Lifongo LL, Mbah JA, Owono LCO, Megnassan E, Mbaze LM, Judson PN, Sippl W, Efange SM. In silico drug metabolism and pharmacokinetic profiles of natural products from medicinal plants in the Congo basin. Silico Pharmacol. 2013;1(1):12.

60. Fulda S. Betulinic acid for cancer treatment and prevention. Int J Mol Sci. 2008;9(6):1096-107.

\section{Publisher's Note}

Springer Nature remains neutral with regard to jurisdictional claims in published maps and institutional affiliations.

\section{Submit your manuscript to a SpringerOpen ${ }^{\circ}$ journal and benefit from:}

- Convenient online submission

- Rigorous peer review

- Open access: articles freely available online

- High visibility within the field

- Retaining the copyright to your article

Submit your next manuscript at $\boldsymbol{\nabla}$ springeropen.com 